\title{
Eco-positioning of airlines: perception versus actual performance
}

\author{
Robert Mayer $^{\mathrm{a}^{*}}$, Tim Ryley ${ }^{\mathrm{b}}$ and David Gillingwater ${ }^{\mathrm{b}}$ \\ ${ }^{a}$ Centre for Air Transport Management, Cranfield University, Cranfield MK43 0TR, UK \\ ${ }^{\mathrm{b}}$ School of Civil and Building Engineering, Loughborough University, Loughborough LE11 \\ 3TU, UK \\ * Tel.: +44 (0)1234 754971, E-mail: r.mayer@cranfield.ac.uk
}

\begin{abstract}
To date there has been little research in air transport into the eco-positioning of airlines, that is, their environmental image relative to other airlines and how actual environmental performance relates to this eco-positioning. This paper identifies the environmental perceptions that passengers hold of twelve airlines and relates these perceptions to airlines' actual environmental performance, using load factors, aircraft age and the atmosfair Airline index as proxies for environmental performance. Based on a survey of over 600 passengers at Liverpool John Lennon Airport, the research analyses air travellers' perception of airlines from an environmental perspective. The results show that while there are significant differences in people's environmental perception of airlines, the eco-positioning of the airlines is not correlated to their actual environmental performance. The results support previous research findings in other industries that in many cases actual performance is less important than communicating environmental messages to the public in creating a superior eco-positioning.
\end{abstract}

KEYWORDS: green marketing, airlines, eco-positioning, green image, passenger perceptions

\section{Introduction}

Research conducted in the United Kingdom demonstrates that the airline sector generally has a poor environmental image in comparison to other industries (Benady, 2007). Therefore, airlines find it difficult to create a green image among the travelling public. This negative perception of airlines with regard to their environmental impact is not unique to the United Kingdom. It can also be found in other countries such as in the United States where $12 \%$ of customers suggest that flying less is one of the best three ways to reduce global warming, even if it is only ranked 8th by actual effectiveness (Bonini and Oppenheim, 2008). However, while the image of airlines based on environmental factors lags behind other industries, within the airline sector there are also significant differences.

The aim of this paper is to analyse the relationship between the environmental image of an airline relative to the environmental image of other airlines (eco-positioning) and their actual environmental performance. The "atmosfair Airline Index", load factors and aircraft age are used as indicators for environmental performance. There is strong support for the need to establish credibility in environmental marketing (e.g. Ottman et al., 2006), yet also support for the focus on quantity (rather than content) of environmental marketing (e.g. Saha and Darnton, 2005). As such the paper will establish if high load factors, young aircraft fleets and a good performance on the atmosfair Airline Index are also reflected in the environmental image that airlines hold. 
In Section 2 a literature review on eco-positioning, airline environmental marketing and green communication is provided. Section 3, the methodology, has a discussion of the three environmental performance indicators and the survey design. The three performance indicators and the airlines' eco-positioning are analysed in Section 4. Finally, the research implications and conclusions are presented in Section 5.

\section{Literature Review}

\subsection{Eco-Positioning}

There is a strong link between customers' perception of a company's brand image and its positioning in the market. Kotler and Armstrong (2010, p. 233) define product positioning as "the way the product is defined by consumers on important attributes - the place the product occupies in consumers' minds relative to competing products". While Kotler and Armstrong refer to products the same is true for individual companies in the market. With regard to green positioning and the link to green image, Saha and Darnton $(2005$, p. 127) point out that "it is a company's green positioning which represents their green image that is perceived by the public". This relationship between green image and eco-positioning means that these two aspects should be analysed together. In comparison to image, positioning does not only refer to consumers' attitudes towards the product or company but puts it into perspective with other products or companies in the market. Similarly to images which are shaped by perceptions, perceptions of a product or company also shape their positioning. The goal of positioning is to generate a competitive advantage in the mind of consumers over competitors' brands based on tangible or intangible product attributes (Gwin and Gwin, 2003). This paper will predominantly address tangible indicators i.e. load factors, aircraft age and an environmental indicator. However it needs to be borne in mind that intangible marketing elements can also affect airlines' environmental image.

Peattie (1995, p. 165) suggests that eco-positioning from a social/physical environment perspective "depends on the consumer's perception of the product and producer in relation to environmental and social problems and their potential solutions." This highlights that positioning both relates to products (or in the case of this research services) and the producer (i.e. the company). With increasing importance of environmental issues in societies, general market position and eco-position become more overlapped. This means that eco-positioning becomes part of the overall perception that consumers hold of a company (Peattie, 1995).

Research from other sectors has identified that green images and related to that green positioning can become an important marketing element to attract and retain customers (Lee et al., 2010). A green brand image can also help companies to generate green brand equity and so use this image as a differentiating factor in the market place i.e. give the company a new position in the market (Chen, 2010).

\subsection{Airline Environmental Marketing}

Peattie (1995) classifies transport as a "dark-grey" product which creates significant environmental issues and achieves low sustainability. This is particularly true for air transport given its growth rate and contribution to radiative forcing. Green airline products are difficult to 
generate because of air transport's environmental impacts. However, airlines have invested in "greener" products over the last few years and communicated these developments.

In general, Shaw (2011) divides the airline product into the two broad categories of aircraft related product features and customer-service related product features.

Aircraft related product features refer to the choice of aircraft itself, cabin configurations and classes of service. Furthermore these features also include network and schedule aspects (timings, frequencies) and punctuality (Shaw, 2011).

With regard to aircraft choice, airlines can introduce a greener product through a range of alterations. Initially, airlines can choose particular airframes that generate fewer greenhouse gas emissions than others. The atmosfair Airline Index (atmosfair, 2011a) indicates that the type of aircraft is the second largest factor in creating $\mathrm{CO}_{2}$ efficiency of airlines, with passenger load factor being the top variable. When looking at aircraft propulsion, the use of turboprop aircraft can reduce airlines' fuel consumption in comparison to jet aircraft and related to that their greenhouse gas emissions. Particularly when environmental costs have to be internalised following government regulation, this can also generate economic benefits on top of any reduction in emissions (Ryerson and Hansen, 2010). Furthermore, aircraft age can also affect emissions with newer aircraft generally producing lower emissions. More recently, with increasing oil prices, airlines can also achieve commercial benefits through the introduction of modern aircraft. These new airframes can result in a reduction in fuel consumption and therefore cost savings in this cost category. As fuel prices have risen in the last few years, fuel has become one of the largest cost categories for airlines (IATA, 2014). Additionally, some airports have started to introduce emission-based charges, which can be another commercial incentive to renew the fleet (Graham, 2014).

Increasing the capacity of aircraft can be a source of environmental improvement for airlines. Airlines can achieve this through using larger aircraft or increasing the number of seats per plane. Particularly for single-aisle aircraft a strong relationship between fuel efficiency and aircraft size can be recognised, while for large aircraft, such as the double deckers, this is less the case (Morrell, 2009). The importance of aircraft size in achieving improved fuel efficiency is also demonstrated by Kling and Hough (2011), who identify a decline in fuel consumption per available tonne kilometre with increasing payload capacity.

The use of fuel is a key issue in achieving a more sustainable air transport system. In response to supply pressures (i.e. high oil prices and limited resources) and subsequent economic incentives, biofuels can also help to address air transport related emissions. Many airlines have started to test biofuels. However, production of biofuels for air transport is not yet on an industrial scale and creates some issues in the production process (Nygren et al., 2009). Sgouridis et al. (2011) suggest that the use of biofuels can help to achieve $\mathrm{CO}_{2}$ savings of between $6.6 \%$ and $17.0 \%$, dependent on the type of biofuel and in conjunction with carbon pricing schemes.

The greening of service-related features has only limited impacts on airlines' environmental efficiency. These parts of the product mix are usually not represented in analyses of airline environmental efficiency (e.g. atmosfair, 2011a; Mason and Miyoshi, 2009). Nevertheless, IATA 
(2011) addresses the environmental benefits of waste management, particularly the role of recycling, as part of airlines' efforts to green their inflight product.

\subsection{Green Communications}

Companies can actively influence their green brand positioning by communicating the environmental elements of the brand in comparison to competitors' brands (Hartmann et al., 2005). Companies have responded to this by increasing their focus on green marketing communications. For example, green advertising has grown significantly, by about $4000 \%$, measured by expenditure in the United Kingdom from 2003 to 2007, with companies aiming to create green credentials through their communication strategy (Smart, 2010).

However, the approach to green communications in environmental marketing is rather ambiguous. At the centre of the discussion is how and whether green communications need to be substantiated and credible or if purely communicating "green" product attributes is sufficient.

Saha and Darnton (2005) suggest that the volume (i.e. how much is communicated about green credentials) has an impact on green positioning rather than whether these claims are accurate or not. Therefore some companies might be seen as less green than other companies, yet they actually might be more environmentally-friendly. This would elevate the importance of market communication with respect to green image and eco-positioning. Contrarily, Ottman et al. (2006, p. 31) have identified credibility as "the foundation of effective green marketing". They advocate that companies need to "employ environmental product and consumer benefit claims that are specific, meaningful, unpretentious, and qualified" (p. 34). Without credibility, companies can be open to scrutiny from environmental groups or regulators (Curtin, 2007; Ottman et al., 2006). For example, easyJet has been criticised in the past for overstating its relative environmental performance: "EasyJet's claims to have more environmentally-friendly airplanes were inaccurately portrayed as such according to ASA [Advertising Standards Authority], [...] following a customer complaint" (Jahdi and Acikdilli, 2009, p. 107). This supports the point that accuracy of green communications is important as this could lead to problems with regulators. Nevertheless, greenwash, the manipulation of a company's image based on environmental claims (Benn and Bolton, 2011), is common practice (Curtin, 2007). Airlines, such as easyJet, Virgin Atlantic, Air New Zealand or Japan Airlines, have all been accused of this practice (Greenpeace, 2008; Pearce, 2009; Pearse, 2012).

Given that the ASA enquiry was based on a consumer complaint, it shows that there are customers that expect credibility and accurate information with regard to airlines' environmental performance. Yet it can be questioned whether this is true for a broader customer base or for certain customer segments.

\subsection{Summary}

The literature review has shown that companies can differentiate themselves from other players in the market through the development of green initiatives and therefore generate a superior ecopositioning. Furthermore, while airlines will find it more difficult to portray themselves as a green company, airlines can introduce a range of measures to reduce their environmental 
impacts. Some airlines have started to incorporate green elements into their marketing mix. With regards to the importance of the actual environmental performance and the credibility of environmental claims, there are different views in the literature, with some advocating the importance of credibility (e.g. Ottman et al., 2006) and others highlighting the importance of market communications and the quantity of green market communications (e.g. Saha and Darnton, 2005).

This paper builds on and extends a previous paper by Mayer et al. (2012). The previous paper identifies that some airlines are perceived to be more environmentally friendly than others, and that some environmental initiatives in the airline sector are seen as more effective than others in addressing environmental impacts. For example, air travellers perceive the use of newer aircraft as the most effective way to address environmental issues (out of a list of nine different measures). While Mayer et al. (2012) identify airlines' green image and environmental marketing measures that are perceived to be effective in addressing environmental concerns, this paper relates airlines' green image and eco-positioning to their actual environmental performance, rather than measures that are perceived to be environmentally-friendly by passengers.

\section{Methodology}

\section{1 atmosfair Airline Index}

Initially, actual green performance must be defined, in order to determine the indicators that measure green performance. While there are a range of environmental performance indicators available, many of which are based on subjective measurements, the atmosfair Airline Index is recognised as a performance indicator based on more objective data (De Grosbois, 2013). Araghi et al. (2014, p. 42) identify the atmosfair airline index as a "recognized labeling system that ranks airlines according to their efficiency". Therefore, the index is frequently referred to and used in academic research (e.g. Åkerman, 2011; Dobruszkes et al., 2014; Gössling and Buckley, 2014; Meißner, 2013). Also in industry, airlines have used their ranking in the atmosfair Airline Index as part of their green marketing communications (e.g. Air Transat, 2011; Monarch, 2011). This illustrates that airlines use this index as a tool to demonstrate environmental performance and credibility. The academic and industry application supports the appropriateness of the atmosfair Airline Index in measuring airline environmental performance in this paper.

The atmosfair Airline Index is published by atmosfair, a non-profit organisation based in Berlin, Germany. The index provides a ranking of airlines, measured by "efficiency points" that relate to greenhouse gas emissions (but not other environmental initiatives). The best case airline on a particular city pair is awarded 100 efficiency points and the least efficient airline zero points. Therefore a higher number of efficiency points indicates a more environmentally-friendly airline. The index considers seven factors that affect $\mathrm{CO}_{2}$ emissions per payload kilometre (e.g. passenger load factors, seat configuration, type of aircraft, cargo capacity). Similar to other studies (e.g. Mason and Miyoshi, 2009), load factor (passenger occupancy) plays a major role in environmental efficiency, followed by aircraft type and seat capacity. Further information on the methodology is provided by atmosfair (2011b). 
Initially in the analysis, the atmosfair Airline Index will be related to airlines' eco-positioning. Given the importance of load factor in the index and given its visibility to passengers, load factor as an environmental performance indicator will be discussed and analysed separately. Aircraft age is not included in the atmosfair Airline Index; according to atmosfair (2011b), it causes little difference in fuel consumption between airlines, however it is used by many airlines (e.g. easyJet, Wizzair, Ryanair) to portray environmental credentials (Mayer et al., 2012). Therefore aircraft age is also compared to the eco-positioning of airlines in this paper.

\subsection{Load Factor}

Changes in the efficiency of air transport play a particular role in the evaluation of the industry in respect to their environmental performance. Efficiency in air transport is dependent on a range of variables, like load factor, system efficiency of operations (e.g. delays) and improved technology (Lee et al., 2009).

One of the most used performance indicators in air transport is the passenger load factor of aircraft. Figure 1 illustrates the development of the passenger load factor for UK airlines from 1989 to 2013. The growth can be attributed to low-cost airlines that operate with higher load factors than most network airlines. However, many full-service network airlines also managed to improve their load factors in the last few years. Load factors exceeding $80 \%$ are not only common in the UK but can also be evident in other airline markets, such as the United States (Zou et al., 2014).

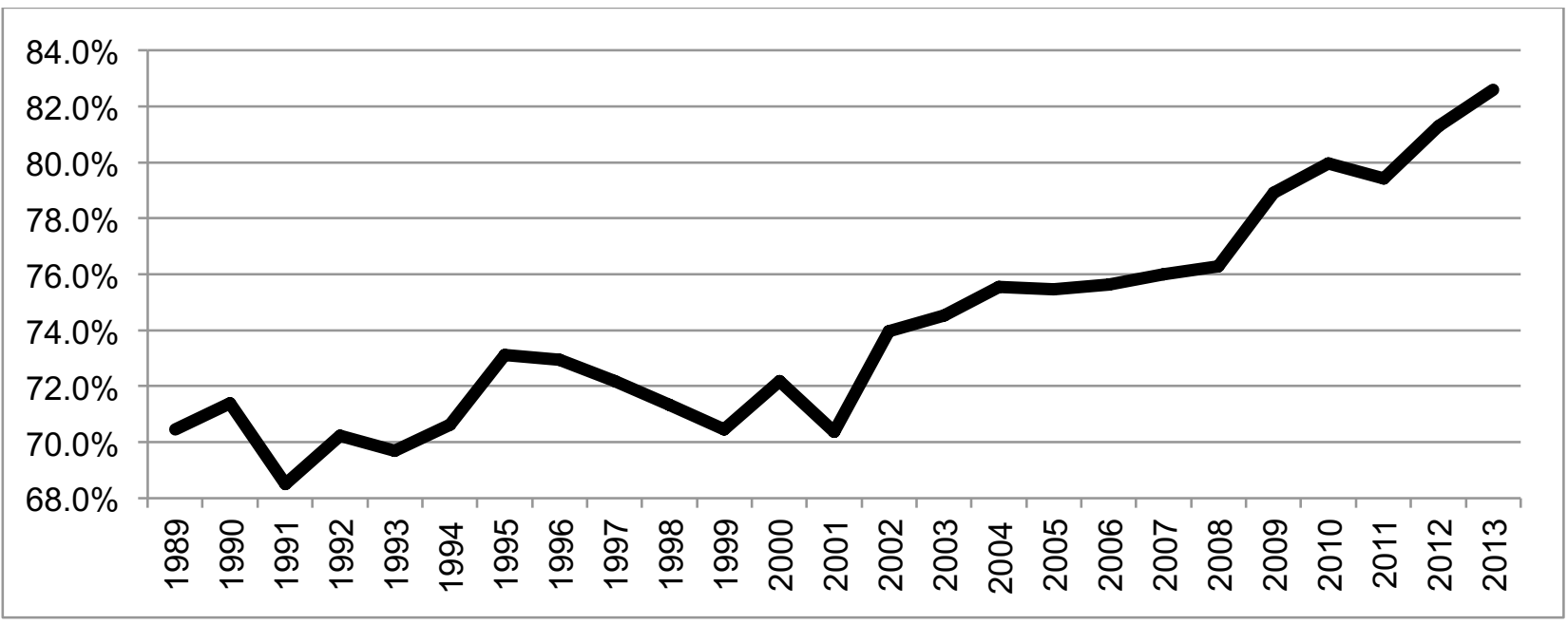

Figure 1: Scheduled Passenger Load Factors of UK Airlines 1989-2013

Source: CAA, 2014

The difference in the load factors for the various business models is related to the nature of their demand. Generally it can be recognised that premium products (full-fare economy, business, first class) generate lower load factors, while products that are predominantly used by leisure travellers generate higher load factors (Holloway, 2008). Furthermore, mainline airlines often achieve higher load factors than regional airlines (Zou et al., 2014).

Economic issues have been a key driver for the increase in load factors and airline efficiency. To support the falling yields in the industry, airlines have had to reduce their unit costs. In particular the emergence of low-cost airlines and the resulting competition with network airlines has had an impact on the efficiency of the industry (Doganis, 2010). While load factors are a common 
indicator for efficiency, from a business perspective the figures have to be borne with caution. It is possible for airlines to generate a loss even at high load factors, if the break-even load factor is high as well. For this reason, load factors should be seen in relation to the respective break-even load factor (Lawton, 2002). Furthermore there is a relationship between load factors and yields. In many markets these two indicators trade off against each other, where a lowering of yields increases the load factor, and vice versa (Holloway, 2008). Environmental benefits can be seen as a by-product of increasing competition in the industry and the requirement to improve efficiency in response to market forces.

With regards to airline efficiency, this paper focuses on load factors as they are of specific interest when evaluating the environmental impacts per passenger travelling. Load factors are an important aspect (rather than seat density and distance flown) in achieving carbon efficiency of airlines. The estimated coefficient for the elasticity of emissions to changes in airline load factors is -0.977 . This means that an increase in airline load factors by $1 \%$ can reduce carbon emissions per passenger kilometre by $0.98 \%$ (Mason and Miyoshi, 2009). In addition, research by Lee at al. (2009, p. 3532) supports the choice of load factors as an indicator for environmental performance of airlines by stating: "A significant factor in limiting $\mathrm{CO}_{2}$ growth from aviation over the past 15 years or so has been load factor, which has increased from 68\% (1989) to 76\% (2006) as a global average." While load factors have increased over time and contributed to mitigating some of the environmental impacts of air transport, it is less likely that this will continue in the future (Lee et al., 2009).

It has to be noted that load factors can be affected by environmental policies. Research demonstrates that emission charges increase load factors and therefore impact efficiency of the sector (Brueckner and Zhang, 2010). This highlights that ring-fenced emission charges can be effective in two ways to address environmental issues, through the generation of income to support environmental activities and through an increase in airline efficiency.

In relation to load factor is the number of seats per aircraft. Airlines can also increase the number of seats to reduce the emissions per available seat kilometre. By increasing the number of seats, the $\mathrm{CO}_{2}$ emissions per passenger kilometre decrease (Kling and Hough, 2011). However, the environmental benefits only materialise if the load factor is constant i.e. more passengers are travelling on the aircraft (Givoni and Rietveld, 2010). Mason and Miyoshi (2009) calculate a coefficient of -0.31 in this respect. This means that an increase of seats on an aircraft by $1 \%$ leads to a reduction in $\mathrm{CO}_{2}$ emissions per passenger kilometre of $0.31 \%$. Seat density, however, is not included in this paper as, given the different fleet mix, airlines are difficult to compare.

To summarise, a number of studies (Kling and Hough, 2011; Lee et al., 2009; Mason and Miyoshi 2009; Miyoshi and Mason, 2009) highlight the importance of airline load factors to achieve environmental efficiencies. Research by Kling and Hough (2011) identify load factor as the second largest driver for carbon efficiency, after an aircraft's fuel economy (which is more difficult to establish given the mix of aircraft and engines that different airlines operate). Furthermore, Mason and Miyoshi (2009) establish that load factor has a higher emissions coefficient than average distance flown and seat density, which again supports the choice of this metric. 


\subsection{Aircraft Age}

Over time the air transport industry has witnessed an increase in fuel efficiency, with average fuel consumption of the world airline fleet decreasing (Nygren et al., 2009). Resulting from that, generally newer aircraft produce fewer emissions than older aircraft (Miyoshi and Mason, 2009). Dray (2013) proposes that new technologies can have a significant impact on reducing airline emissions. Furthermore, as aircraft get older, their fuel performance, and therefore their environmental performance, decreases. However, with regards to environmental improvement through fleet renewal, a key issue is that newer aircraft are often used to cater for new demand and not necessarily replacing older, less fuel efficient, aircraft (Dray, 2013). Miyoshi and Mason (2009) also identify newer aircraft, combined with other factors, as way to reduce carbon emissions per passenger kilometre. Indicating the magnitude of the use of newer aircraft in reducing emissions, Dray (2013, p. 69) highlights that "the greatest scope for reducing the emissions of the global aircraft fleet, (...), is likely to come from policies aimed at influencing the rate of technology development." In addition, Brueckner and Zhang (2010) identify the use of policy instruments (in their case emissions charges) as a way to raise aircraft fuel efficiency. For example, in Europe, industry and governments aim to decrease fuel consumption of aircraft, with fleet replacement being a core element of this policy goal (Nygren et al., 2009). Kling and Hough (2011) see a continuing trend in aircraft becoming more environmentally friendly in response to increasing competition among aircraft manufacturers for more fuel-efficient aircraft.

Aircraft age can be a "visible" element of the marketing mix to passengers, similarly to load factor. However, upgrades and refurbishments can conceal an aircraft's true age which therefore could make it difficult to passengers to recognise the actual aircraft age. While aircraft upgrades (e.g. adding winglets) can generate marginal environmental performance improvements to older aircraft, they can also extend the life cycle of aircraft (Dray, 2013). However, Sgouridis et al. (2011) identify short-term improvements of aircraft as particularly effective in reducing $\mathrm{CO}_{2}$ emissions.

While there is little doubt that newer aircraft are more fuel efficient than older aircraft, aircraft age is not included in the atmosfair Airline Index as differences between airlines' fuel consumption as a result of different aircraft age and maintenance are less than $1 \%$. Other factors such as load factors or seat configuration have a more substantial impact on $\mathrm{CO}_{2}$ efficiency (atmosfair, 2011b). Despite this, many airlines refer to their young fleet in their green market communications (Mayer et al., 2012). This must be done with caution, as for example in the UK the ASA (2011) upheld a complaint against easyJet. The ASA ruled that claiming that newer planes are less damaging to the environment purely because of their age is misleading as other factors need to be taken into consideration as well.

While load factors have a clear impact on fuel efficiency, the impact of aircraft age is less obvious and there seems to be less consent in the literature about its magnitude in achieving environmental benefits. However, it is generally accepted that newer aircraft, all other factors being equal, are more environmentally-friendly than older aircraft (ASA, 2011; Dray, 2013; Miyoshi and Mason, 2009). Despite the omission of aircraft age in the atmosfair Airline Index, in this paper aircraft age is considered and included in the analysis. As indicated above, a newer aircraft can be a "visible" element of an airline's marketing mix and it is frequently used in 
airlines' green marketing communications. Therefore there is a strong rationale to analyse the relationship between airlines' fleet age and their eco-positioning.

\subsection{Passenger Survey on Perceptions of Environmental Issues in Air Transport}

Data to establish airlines' eco-positioning was gathered through a large quantitative survey of over 600 respondents at Liverpool John Lennon Airport (LPL) in 2010. Following a pilot survey in March 2010, over eight days nearly 1,000 passengers at the airport were randomly approached to fill in a self-completion questionnaire, achieving a response rate of $61.3 \%$. Besides socioeconomic data, information was collected on passengers' attitude towards environmental issues in air transport. For this paper, the data stems from passengers' environmental perception of airlines. Air travellers were presented with a list of twelve airlines, covering different business models, including all airlines that operated to the airport at the time of the survey, as well as some of the largest UK charter and full-service network airlines. A list of airlines included in the survey can be found in Table 1 .

\begin{tabular}{|lll|}
\hline $\begin{array}{l}\text { Full-service network } \\
\text { airlines }\end{array}$ & - Bmi (mainline) & Operated from LPL in 2010: No \\
& - Kritish Airways & Operated from LPL in 2010: No \\
& - & Operated from LPL in 2010: Yes \\
\hline Regional airlines & - Flybe & Operated from LPL in 2010: No \\
\hline Charter airlines & - & Operated from LPL in 2010: Yes \\
& - Thomas Cook Airlines & Operated from LPL in 2010: No \\
\hline Low-cost airlines & - bmibaby & Operated from LPL in 2010: No \\
& - easyJet & Operated from LPL in 2010: No \\
& - Ryanair & Operated from LPL in 2010: Yes \\
& - Wizz Air & Operated from LPL in 2010: Yes \\
& & Operated from LPL in 2010: Yes \\
\hline
\end{tabular}

Table 1: Airline sample

NB: bmibaby ceased operations in 2012 and Bmi (mainline) was integrated into British Airways in 2012. Therefore both airlines no longer operate (2014).

Respondents rated the twelve airlines on a five-point Likert scale from "very environmentallyfriendly" to "very environmentally-unfriendly". Results from the Likert scales were treated as interval data $(1=$ very environmentally-friendly; $2=$ somewhat environmentally-friendly; $3=$ neither environmentally-friendly nor unfriendly; 4 = somewhat environmentally unfriendly; $5=$ very environmentally unfriendly) which enabled calculation of the means of the airlines' perceived environmental image and so their eco-positioning. While there have been discussions about the appropriateness of treating Likert scales as interval data rather than ordinal data (Cohen et al., 2007; Keller, 2008; Kuzon et al., 1996), they have been commonly applied in research (Bryman and Cramer, 2005).

The survey provides quantitative data on airlines' eco-positioning, whereas load factors and average aircraft age for 2010, the year when the survey was conducted, are retrieved from Flightglobal Pro's database (Flightglobal, 2012). This enables the correlation of the variables (eco-positioning vs. load factors and eco-positioning vs. average aircraft age) and so addresses the aim of this paper, to analyse the relationship between the environmental image of an airline 
relative to the environmental image of other airlines (eco-positioning) and their actual environmental performance.

Load factor and aircraft age, as well as airline image scores, were checked for normality. While the Kolmogorov-Smirnov test does not show a significant non-normality for either of the variables, evaluating kurtosis, skewness and histograms suggest that the data is not normally distributed. This is particularly true for load factor with the values for skew and kurtosis being -1.122 and 1.018 respectively. Therefore, a non-parametric correlation is chosen. Kendall's tau $(\tau)$ is used as the data set is relatively small (Field, 2009).

Efficiency points, the measurement used to establish environmental efficiency in the atmosfair Airline Index, are obtained from the 2012 atmosfair Airline Index, the year closest to the passenger survey. Originally for methodological reasons (i.e. subsidies to reduce fares and increase demand; more distant airports that require longer ground transportation), low-cost airlines were not included in the main atmosfair Airline Index 2012 and therefore cannot be compared to the perceived environmental friendliness with other airlines. As the 2012 index is closest in time to the dates of the survey, this edition is used. Therefore, the index includes six airlines (Bmi, British Airways, KLM, Thomas Cook Airlines, Thomson Airways and Virgin Atlantic) that are also included in the current sample.

\section{Analysis: Perception vs Actual Performance}

\subsection{Characteristics of the Sample}

The respondents to the passenger survey varied in age, occupation, gender and income, but could be considered representative of passengers flying from the airport. A survey conducted by the Civil Aviation Authority at Liverpool John Lennon Airport the same time shows no significant differences with regard to the age and gender composition between the two samples. Besides questions on people's perception of airlines' green image, also socio-demographic data were collected. While over $90 \%$ of respondents provided information on age, gender and occupation, fewer gave information on their income. Table 2 gives an overview of the sample.

Regarding the environmental performance indicators used in this study, a large majority of respondents $(89.1 \%)$ perceive the use of newer aircraft to reduce the environmental impacts of aviation as either very effective or somewhat effective. In comparison, only $63.8 \%$ identify the increase in seats per aircraft as effective. There are some differences between female and male respondents when it comes to the way in which airlines address environmental issues. While in general, female respondents perceive measures to address the environmental impact of air transport as more effective than male respondents, male respondents particularly support the use of newer aircraft. The increase of seats per aircraft shows no significant difference between the two genders $(p>0.05)$. There is also no statistically significant difference in the perceived effectiveness of increasing the number of seats based on age, annual income or occupation $(p>0.05)$. Furthermore no significant differences in the perceived effectiveness of newer aircraft by annual income or occupation $(p>0.05)$ can be identified, however differences based on age can be noted $(p<0.05)$, with respondents over 55 years tending to be more supportive of this measure. 


\begin{tabular}{|c|c|c|}
\hline \multirow{2}{*}{$\begin{array}{l}\text { Gender } \\
(n=593)\end{array}$} & Male & $48.2 \%$ \\
\hline & Female & $51.8 \%$ \\
\hline \multirow{6}{*}{$\begin{array}{l}\text { Age } \\
(n=593)\end{array}$} & $18-24$ & $19.1 \%$ \\
\hline & $25-34$ & $22.0 \%$ \\
\hline & $35-44$ & $15.2 \%$ \\
\hline & $45-54$ & $15.4 \%$ \\
\hline & $55-64$ & $18.1 \%$ \\
\hline & 65 and over & $10.3 \%$ \\
\hline \multirow{6}{*}{$\begin{array}{l}\text { Occupation } \\
(\mathrm{n}=576)\end{array}$} & Full-time employment & $44.8 \%$ \\
\hline & Permanently retired from work & $17.9 \%$ \\
\hline & In Education & $11.6 \%$ \\
\hline & Self-employed & $11.1 \%$ \\
\hline & Part-time employment & $9.4 \%$ \\
\hline & Other & $5.2 \%$ \\
\hline \multirow{7}{*}{$\begin{array}{l}\text { Personal Annual Income } \\
(\mathrm{n}=385)\end{array}$} & Less than $£ 10,000$ & $15.3 \%$ \\
\hline & $£ 10,001-£ 20,000$ & $25.7 \%$ \\
\hline & $£ 20,001-£ 30,000$ & $19.5 \%$ \\
\hline & $£ 30,001-£ 40,000$ & $15.6 \%$ \\
\hline & $£ 40,001-£ 50,000$ & $10.1 \%$ \\
\hline & $£ 50,001-£ 60,000$ & $4.2 \%$ \\
\hline & More than $£ 60,000$ & $9.6 \%$ \\
\hline
\end{tabular}

Table 2: Overview of the Sample

In the next sections, the three environmental indicators will be analysed relative the airlines' ecopositioning.

4.2 atmosfair Airline Index and Eco-positioning

This index is based on combining several measurements into one indicator. Six of the twelve airlines are included in this analysis. Nevertheless, the analysis shows similar results to the other indicators, i.e. that the eco-positioning is not related to environmental performance (Figure 2). However it can be noted that the gap between Virgin Atlantic and e.g. KLM is substantial. While Virgin Atlantic has the best eco-positioning, it has the worst environmental performance of the six airlines. The data also shows the superior performance of the two charter airlines; however, this is not reflected in their eco-positioning.

Correlating perceived environmental friendliness and average efficiency points from the atmosfair Airline Index shows that these two variables are not significantly correlated $(\tau=0.6$, $\mathrm{p}>0.05$ ). However it can be noted that the correlation coefficient is positive, which would indicate that less environmentally-friendly airlines (measured by the atmosfair Airline Index) are perceived to be more environmentally-friendly by respondents. Overall this result also supports 
the other findings in this paper that environmental performance does not positively affect the eco-positioning of airlines.

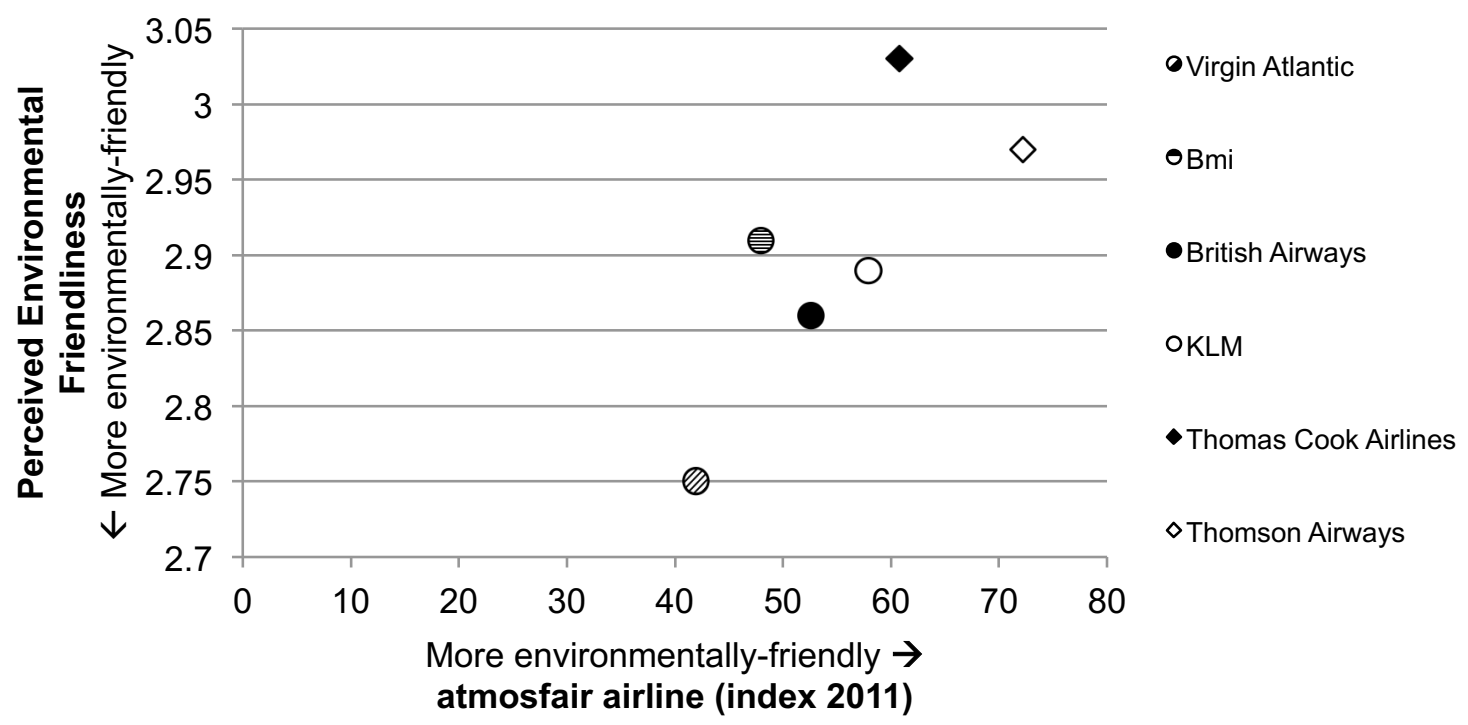

Figure 2: atmosfair Airline Index (2012) and Eco-positioning Source: atmosfair Airline Index from atmosfair (2011a)

\subsection{Load Factor and Eco-Positioning}

Load factor is an indicator that can easily be observed by passengers. High load factors are particularly noticeable for passengers through increased aircraft boarding times and crowding on board the aircraft (Rhoades and Waguespack, 2004). Therefore passengers have a negative attitude towards high load factors as it creates discomfort, increases the possibility of the flight being overbooked or limiting purchasing opportunities on a sold-out flight (Brueckner and Zhang, 2010). While there are cost and environmental benefits from higher load factors, they can negatively affect passengers which may affect their support for higher load factors to reduce the environmental impacts of air transport.

Figure 3 illustrates the airlines' eco-positioning and their respective load factors. Full-service network airlines are displayed as circles, charter airlines as diamonds, low-cost airlines as triangles and regional airlines as squares.

The figure demonstrates that four airlines (Ryanair, Wizz Air, Thomas Cook Airlines and Thomson Airways) have a relatively high load factor and therefore a high environmental efficiency (when load factor is used as a proxy). Yet their perceived environmental friendliness is below the sample average of 2.95 , where a lower score on the $y$-axis indicates a more environmentally-friendly image and a high score a less environmentally-friendly image. easyJet also shows a high load factor for 2010 , yet achieves a much better environmental position.

Figure 3 also highlights that the full-service network airlines are relatively closely clustered while low-cost airlines are more dispersed. The two charter airlines also show a similar profile 
(Thomas Cook Airlines and Thomson Airways), though as only two charter airlines are presented in this study, no further conclusion can be drawn from this.
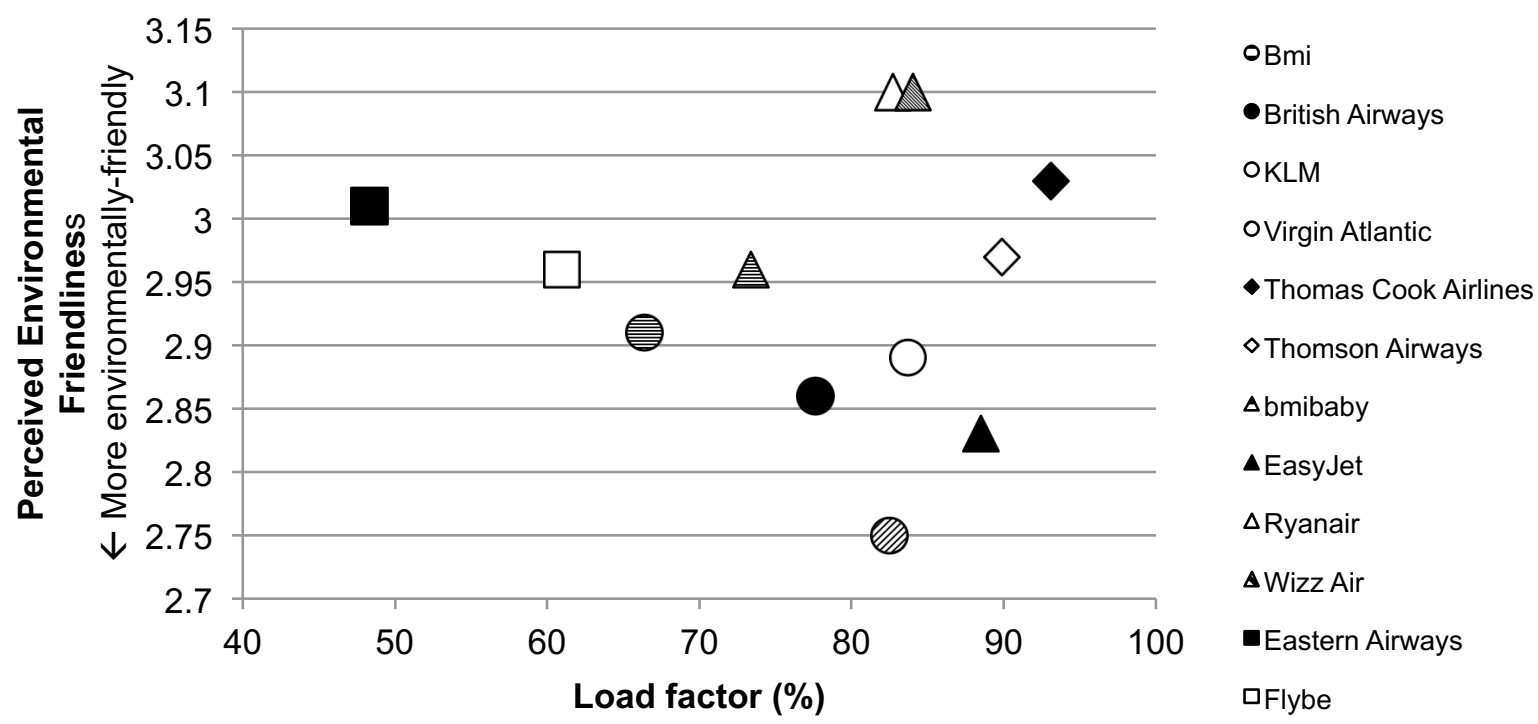

Figure 3: Load factors and eco-positioning Source: Load factors from Flightglobal (2012)

When analysing the load factors and the perceived environmental friendliness of the twelve airlines in the sample, no significant correlation between the two variables could be identified $(\tau=0.031, \mathrm{p}>0.05)$. This demonstrates that environmental performance (measured by load factor) does not positively affect eco-positioning. However, it can be noted that Ryanair and Wizz Air, and to some extent Thomas Cook Airlines and Thomson Airways, are outliers. Removing these four airlines from the analysis shows a significant correlation between the two variables $(\tau=-0.691, \mathrm{p}<0.05)$. Ryanair and Wizz Air achieve a very similar eco-positioning. Both airlines being ultra low-cost airlines have a different profile to other airlines in the sample. In the case of the two charter airlines, Thomas Cook Airlines and Thomson Airways, the typically very high load factors of charter airlines, might require a separate analysis of this group.

\subsection{Aircraft Age and Eco-positioning}

Figure 4 illustrates the average aircraft age and the eco-positioning of the airlines in the sample. The figure highlights that airlines with a relatively young fleet (i.e. Ryanair and Wizz Air) are not necessarily perceived as environmentally-friendly by passengers. It is noticeable that Ryanair and Wizz Air hold a very similar position in both Figure 3 and Figure 4. Contrarily the other big low-cost airline, easyJet, achieved a higher environmentally-friendly score with similar aircraft age and load factor as Ryanair and Wizz Air. As in the previous section, the full-service network airlines are clustered in the centre of the graph (with the exception of Virgin Atlantic, that has a significantly better eco-positioning than the other airlines), as well as the two charter airlines holding a similar position. 
When analysing the average age of the twelve airlines' fleets, no significant correlation between actual aircraft age and perceived environmental friendliness can be identified $(\tau=-0.031$; $\mathrm{p}>0.05)$. Unlike the case of load factors, excluding Ryanair and Wizz Air from the analysis does not change the results $(\tau=0.327, \mathrm{p}>0.05)$, as there is no statistically significant correlation between the two variables.

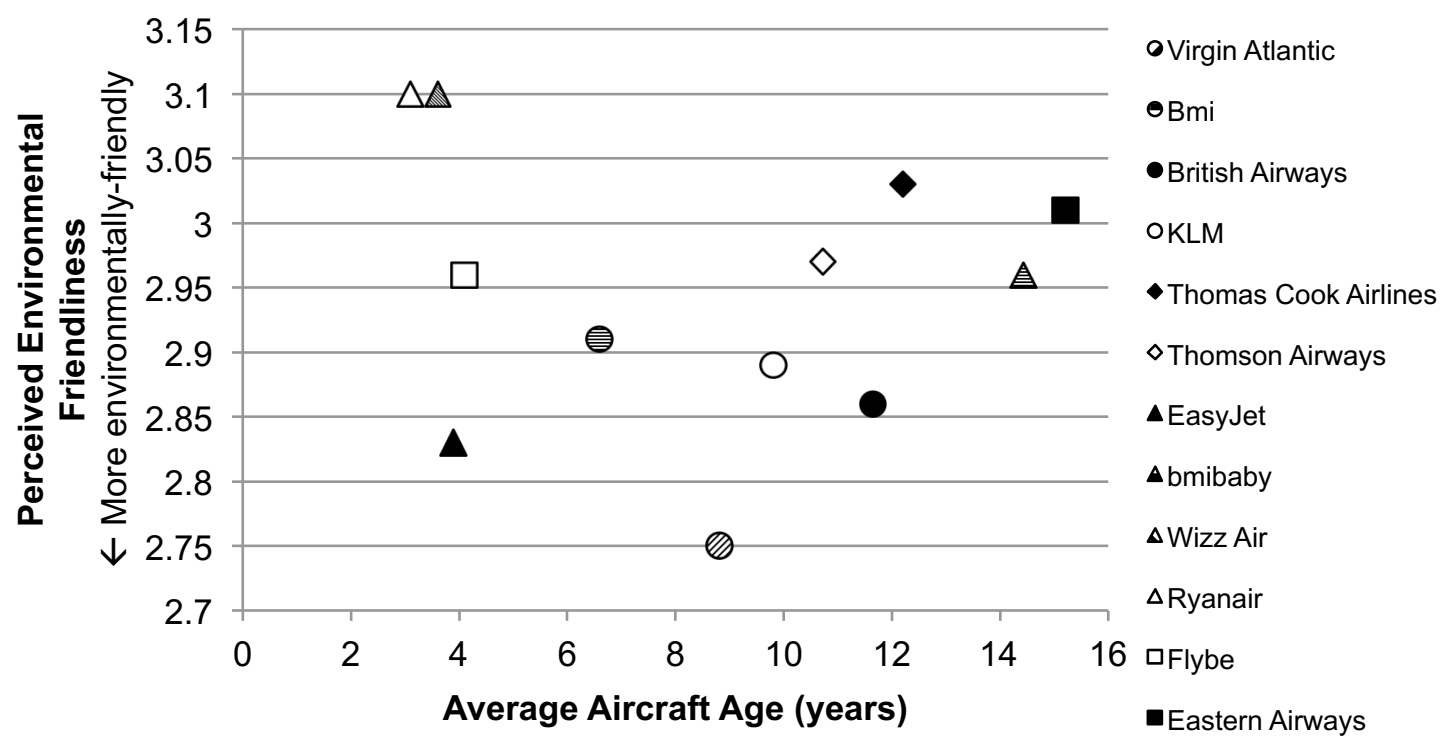

Figure 4: Average Aircraft Age (2010) and Eco-positioning

Source: Aircraft age from Flightglobal (2012)

This illustrates that having a young fleet is not enough for airlines to generate a positive green image and improve their eco-positioning. Given all other factors (e.g. load factors, seat configuration) equal, low aircraft age as a proxy for good environmental performance does not affect green eco-positioning. Green performance needs to be communicated as part of an airline's marketing communication. This can be recognised by the environmental image of Virgin Atlantic and easyJet, two airlines that have focused their market communications on environmental aspects (Holden, 2009; Kotler and Keller, 2012).

\section{Conclusions}

Using three environmental performance indicators (load factor, aircraft age and the atmosfair Airline index), the eco-positioning of a sample of airlines has been evaluated. The data demonstrates that there is no statistically-significant correlation between airlines' perceived green image and their actual environmental performance. For example, Ryanair achieves high load factors and has a relatively young fleet which means that its emissions per passenger kilometre are relatively low. Yet, the airline is perceived as less environmentally-friendly than the other airlines in the sample.

This highlights the importance of green communications in green airline marketing. It seems more important to communicate green credentials and performance, than actually achieving relatively low environmental impact. This is in contrast to work by Ottman et al. (2006) and Curtin (2007) who advocate the importance of credibility of environmental claims. From a 
practical perspective it is important for airlines to focus particularly on communications. However, this does not mean that airlines can make environmental claims that are completely unsubstantiated. There needs to be some evidence in supporting green claims. This evidence seems to be less expected by air travellers but could lead to issues with advertising regulators and environmental groups. Unsubstantiated environmental claims can lead to claims of greenwash, especially from environmental groups. While passengers seem to be less critical, any negative publicity needs to be avoided and whenever possible mitigated, and green credentials should be established. However, the research from this paper suggests that these environmental inputs in the marketing mix do not have to be "better" or more effective than those of other companies in the sector, but that they need to be well communicated. Many airlines that have introduced a green marketing mix have been accused of greenwash (Greenpeace, 2008; Pearce, 2009; Pearse, 2012), therefore the selection of green marketing initiatives is important from that perspective. Furthermore, airlines need to be prepared to counter claims of greenwash.

Besides the negative publicity of greenwash, false or unproven claims can also lead to legal issues. For example, a complaint against easyJet for an advertisement ("easyJet emits $22 \%$ less $\mathrm{CO}_{2}$ ") that highlighted its environmental achievements was judged to be misleading by the UK Advertising Standards Authority (Advertising Standards Authority, 2008). For airlines this means that they need to find a fine balance between communicating green aspects of their green marketing mix, while adhering to advertising standards guidelines. This would also suggest that less specific claims are more appropriate as actual, tangible aspects of the marketing mix which do not influence an airline's eco-positioning.

This paper has demonstrated that actual environmental performance does not affect the ecopositioning of airlines but that there seem to be other latent factors that need to be taken into consideration as well. Further research into identifying other factors that affect airlines' ecopositioning would make a valuable contribution. 


\section{References}

Advertising Standards Authority (2008). ASA Adjudication on easyJet Airline Co Ltd. [online]. Available at: http://www.asa.org.uk/Rulings/Adjudications/2008/7/easyJet-Airline-CoLtd/TF_ADJ_44608.aspx [accessed 11 November 2014].

Advertising Standards Authority (2011). ASA Adjudication on easyJet Airline Co Ltd. [online]. Available at: http://asa.org.uk/Rulings/Adjudications/2011/2/easyJet-Airline-CoLtd/TF_ADJ_49663.aspx\#.VL0aLsbZe-I [accessed 11 November 2014].

Air Transat (2011). Air Transat ranked first in the world in the "Atmosfair Airline Index" - in the long-haul category - for its environmental performance [online]. Available at http://www.airtransat.ca/en/About-Air-Transat/Awards-Rewards-andRecognition?ID=2921\&type=gamme\&tmpl=GEN\#atmosfair [accessed 11 November 2014].

Åkerman, J. (2011). The role of high-speed rail in mitigating climate change - The Swedish case Europabanan from a life cycle perspective. Transportation Research Part D: Transport and Environment, 16/3, pp. 208-217

Araghi, Y., Kroesen, M., Molin, E., and van Wee, B. (2014). Do social norms regarding carbon offsetting affect individual preferences towards this policy? results from a stated choice experiment. Transportation Research Part D: Transport and Environment, 26, pp. 42-46.

atmosfair (2011a). atmosfair Airline Index 2012. atmosfair, Berlin.

atmosfair (2011b). atmosfair Airline Index: Documentation of the methodology. atmosfair, Berlin.

Benady, D. (2007). Brands show true colours [online]. Available at: http://www.marketingweek.com/2007/05/30/brands-show-true-colours/ [accessed 11 November 2014].

Benn, S. and Bolton, D. (2011). Key Concepts in Corporate Social Responsibility. Sage, London. Bonini, S. and Oppenheim, J. (2008). Cultivating the Green Consumer. Stanford Social Innovation Review, Fall 2008, pp. 56-61.

Brueckner, J.K. and Zhang, A. (2010). Airline emission charges: Effects on airfares, service quality, and aircraft design. Transportation Research Part B, 44/8, pp. 960-971.

Bryman, A. and Cramer, D. (2005). Quantitative Data Analysis with SPSS 12 and 13. Routledge, London/New York.

CAA (2014). Main Outputs of UK Airlines (1989 - 2012) in Seat-kilometres Available and Used [online]. Civil Aviation Authority. Available at:

http://www.caa.co.uk/docs/80/airline_data/2012Annual/Table_0_1_4_Main_Outputs_of_UK_Ai rlines_1989_2012_Seat_Km_Avail_Used.pdf [accessed 11 November 2014].

Chen, Y.-S. (2010). The Drivers of Green Brand Equity: Green Brand Image, Green Satisfaction, and Green Trust. Journal of Business Ethics, 93, pp. 307-319. 
Cohen, L., Manion, L. and Morrison, K. (2007). Research Methods in Education. 6th ed., Routledge, London/New York.

Curtin, T. (2007). Managing Green Issues. 2nd ed., Palgrave Macmillan, Basingstoke.

De Grosbois, D. (2013). Corporate social performance in tourism. In Holden, A., \& Fennell, D. A. (2013). The Routledge Handbook of Tourism and the Environment. London: Routledge.

Dobruszkes, F., Dehon, C. and Givoni, M. (2014). Does European high-speed rail affect the current level of air services? An EU-wide analysis. Transportation Research Part A: Policy and Practice, 69, pp. 461-475

Doganis, R. (2010). Flying off Course: Airline Economics and Marketing. 4th ed., Routledge, London.

Dray, L. (2013). An analysis of the impact of aircraft lifecycles on aviation emissions mitigation policies. Journal of Air Transport Management, 28, pp. 62-69.

Field, A. (2009). Discovering Statistics using SPSS. 3rd ed., Sage, London.

Flightglobal (2012). Flightglobal pro [online]. Avialable at: pro.flightglobal.com [accessed 28th August 2012].

Givoni, M., and Rietveld, P. (2010). The environmental implications of airlines' choice of aircraft size. Journal of Air Transport Management, 16/3, pp. 159-167.

Gössling, S. and Buckley, R. (2014). Carbon labels in tourism: persuasive communication?. Journal of Cleaner Production, (in press).

Graham, A. (2014). Managing Airports. 4th ed., Routledge, London.

Greenpeace (2008). Virgin guilty of "high altitude greenwash" [online]. Greenpeace. Available at: http://www.greenpeace.org.uk/media/press-releases/virgin-guilty-of-high-altitude-greenwash20080224 [accessed 11 November 2014].

Gwin C. F. and Gwin, C. R. (2003). Product attributes model: a tool for evaluating brand positioning. Journal of Marketing Theory and Practice, 11/2, pp. 30-42.

Hartmann, P., Apaolaza Ibáñez, V. and Forcada Sainz, F. J. (2005). Green branding effects on attitude: functional versus emotional positioning strategies. Marketing Intelligence \& Planning, 23/1, pp. 9-29.

Holden, A. (2009). The Environment-Tourism Nexus: Influence of Market Ethics. Annals of Tourism Research, 36/3, pp. 373-389.

Holloway, S. (2008). Straight and Level: Practical Airline Economics. 3rd ed., Ashgate, Aldershot.

IATA (2011). A Waste of Waste [online]. International Air Transport Association. Available at: http://airlines.iata.org/analysis/a-waste-of-waste [accessed 11 November 2014]. 
IATA (2014). Airlines Financial Monitor March-April 2014 [Online]. International Air Transport Association. Available at http://www.iata.org/whatwedo/Documents/economics/airlines-financial-monitor-apr-14.pdf [accessed 29 October 2014].

Jahdi, K. S. and Acikdilli, G. (2009). Marketing communications and Corporate Social Responsibility (CSR): Marriage of Convenience or Shotgun Wedding?. Journal of Business Ethics, 88, pp. 103-113.

Keller, G. (2008). Managerial Statistics. 8th ed., South-Western Cengage Learning, Mason.

Kling, M. and Hough, I. (2011). Air Travel Carbon And Energy Efficiency. Brighter Planet, Vermont.

Kotler, P. and Armstrong, G. (2010). Principles of Marketing. 13th ed., Prentice Hall, Upper Saddle River.

Kotler, P. and Keller, K. L. (2012). Marketing Management. 14th ed., Pearson Education, Harlow.

Kuzon, W. M., Urbanchek, M. G. and McCabe, S. (1996). The Seven Deadly Sins of Statistical Analysis. Annals of Plastic Surgery., 37/3, pp. 265-272.

Lawton, T. C. (2002). Cleared for Take-Off: Structure and strategy in the low fare airline business. Ashgate, Aldershot.

Lee, D. S., Fahey, D. W., Piers. M. F., Newton, P. J., Wit, R. D. N., Lim, L. L., Owen, B. and Sausen, R. (2009). Aviation and global climate change in the 21st century. Atmospheric Environment, 43, pp. 3520-3537.

Lee, J.-S., Hsu, L.-T., Han, H. and Kim, Y. (2010). Understanding how consumers view green hotels: how a hotel's green image can influence behavioural intentions. Journal of Sustainable Tourism, 18/7, pp. 901-914.

Mason, K. and Miyoshi, C. (2009). Airline Business Models and their respective carbon footprint: Final Report, Omega/Manchester Metropolitan University.

Mayer, R., Ryley, T. and Gillingwater, D. (2012), Passenger perceptions of the green image associated with airlines. Journal of Transport Geography, 22, pp. 179-186.

Meißner, N. (2013). The incentives of private companies to invest in protected area certificates: How coalitions can improve ecosystem sustainability. Ecological Economics, 95, pp. 148-158.

Miyoshi, C. and Mason, K. J. (2009). The carbon emissions of selected airlines and aircraft types in three geographic markets. Journal of Air Transport Management, 15, pp. 138-147.

Monarch (2011). 2011 News - Flights - Monarch is world's greenest airline [online. Avialable at: http://www.monarch.co.uk/news/flights/2011-news/monarch-greenest-airline [accessed 11 November 2014]. 
Morrell, P. (2009). The potential for European aviation CO2 emissions reduction through the use of larger jet aircraft. Journal of Air Transport Management, 15, pp. 151-157.

Nygren, E., Aleklett, K., and Höök, M. (2009). Aviation fuel and future oil production scenarios. Energy Policy, 37/10, pp. 4003-4010.

Ottman, J. A., Stafford E. R. and Hartman, C. L. (2006). Avoiding Green Marketing Myopia. Environment, 48/5, pp. 22-36.

Pearse, G. (2012). Greenwash: Big Brands and Carbon Scams. Black Inc., Collingwood.

Pearce, F. (2009). Greenwash: easyJet's carbon claims written on the wind [online]. The Guardian. Available at: http://www.guardian.co.uk/environment/blog/2009/jul/23/easyjetclimate-change-claims [accessed 11 November 2014].

Peattie, K. (1995). Environmental Marketing Management: Meeting the Green Challenge. Pitman Publishing, London.

Rhoades, D. L. and Waguespack Jr, B. P. (2004). Service and safety quality in US airlines: preand post-September 11th. Managing Service Quality, 14/4, pp. 307-316.

Ryerson, M. S. and Hansen, M (2010). The potential of turboprops for reducing aviation fuel consumption. Transportation Research D, 15, pp. 305-314.

Saha, M and Darnton, G. (2005). Green Companies or Green Con-panies: Are Companies Really Green, or Are They Pretending to Be?. Business and Society Review, 110/2, pp. 117-157.

Sgouridis, S., Bonnefoy, P. A. and Hansman, R. J. (2011). Air Transportation in a carbon constrained world: Long-term dynamics of policies and strategies for mitigating the carbon footprint of commercial aviation. Transportation Research Part A, 45, pp. 1077-1091.

Shaw, S. (2011). Airline Marketing and Management. 7th ed., Ashgate, Aldershot.

Smart, B. (2010). Consumer Society: Critical Issues and Environmental consequences. Sage, London.

Zou, B., Elke, M., Hansen, M. and Kafle, N. (2014). Evaluating air carrier fuel efficiency in the US airline industry. Transportation Research Part A: Policy and Practice, 59, pp. 306-330. 
2015-03-16

\section{Eco-positioning of airlines: perception versus actual performance}

Mayer, Robert

Elsevier

Mayer R, Ryley T, Gillingwater D. (2015) Eco-positioning of airlines: perception versus actual performance. Journal of Air Transport Management, Volumes 44-45, May-June 2015, pp. 82-89 https://doi.org/10.1016/j.jairtraman.2015.03.003

Downloaded from Cranfield Library Services E-Repository 